\title{
Anti-mitotic activity towards sea urchin eggs of dichloromethane fraction obtained from Allamanda schottii Pohl (Apocynaceae)
}

\author{
Louisa M. A. Sousa, ${ }^{1}$ Rubens L. Monte Neto, ${ }^{2}$ Dionezine F. Navarro Schmidt, ${ }^{3}$ \\ Márcia R. Oliveira ${ }^{*, 1,2}$ \\ ${ }^{1}$ Departamento de Biologia Molecular, Universidade Federal da Paraíba, 58051-970 João Pessoa-PB, Brasil, \\ ${ }^{2}$ Laboratório de Tecnologia Farmacêutica, Universidade Federal da Paraíba, 58051-900, João Pessoa-PB, Brasil, \\ ${ }^{3}$ Departamento de Ciências Farmacêuticas, Universidade Estadual de Ponta Grossa, 84030-900 Ponta Grossa-PR, \\ Brasil
}

\begin{abstract}
RESUMO: "Atividade anti-mitótica da fração diclorometano obtida de Allamanda schottii Pohl (Apocynaceae) sobre ovos do ouriço do mar." Allamanda (Apocynacea) é um gênero de arbustos escandentes conhecido por produzir compostos com várias atividades biológicas. Trabalhos anteriores têm mostrado um efeito anti-proliferativo do extrato etanólico de Allamanda schottii sobre células leucêmicas. O presente trabalho foi realizado para avaliar o efeito da fração diclorometano, obtida de Allamanda schotti, sobre os ovos de ouriço-do-mar de Echinometra lucunter, como um modelo multicelular para estudar atividade anti-tumoral. Nossos resultados mostram uma inibição do desenvolvimento dos ovos de uma maneira dose-dependente na presença da fração diclorometano. Os valores de $\mathrm{IC}_{50}$ para a primeira e terceira clivagem e para o estágio de blástula foram de $103,7 \mu \mathrm{g} / \mathrm{mL}, 33.1 \mu \mathrm{g} / \mathrm{mL}$ e $10,2 \mu \mathrm{g} / \mathrm{mL}$, respectivamente. Estes resultados também demonstram um efeito acumulativo da fração sobre os embriões do ouriço-do-mar. No presente trabalho, esta expressiva atividade anti-mitótica da fração diclorometano sobre o desenvolvimento embrionário do ouriço-do-mar, um modelo multicelular, reforça o potencial antitumoral de Allamanda schotti.
\end{abstract}

Unitermos: Allamanda schottii, ouriço do mar, atividade anti-mitótica, anti-tumoral.

\begin{abstract}
Allamanda (Apocynaceae) is a genus of climbing shrubs known for producing compounds with a range of biological activities. Previous works have shown the anti-proliferative effect of the ethanolic extract of Allamanda schottii on leukemic cells. The present work was conducted to evaluate the effects of dichloromethane fraction, obtained from Allamanda schottii, on sea urchin Echinometra lucunter eggs, as a multicellular model for evaluating anti-tumor activity. Our results show an inhibition of sea urchin development in a dose-dependent manner in the presence of dichloromethane fraction. $\mathrm{The} \mathrm{IC}_{50}$ values for first and third cleavage and blastulae stage were $103.7 \mu \mathrm{g} / \mathrm{mL}, 33.1 \mu \mathrm{g} / \mathrm{mL}$ and $10.2 \mu \mathrm{g} / \mathrm{mL}$, respectively. These results also demonstrate the cumulative effect of this fraction on sea urchin embryos. In the present work, the expressive anti-mitotic activity of dichloromethane fraction towards sea urchin eggs, a multicellular model, reinforces the anti-tumor potential of the Allamanda schotti.
\end{abstract}

Keywords: Allamanda schottii, sea urchin, anti-mitotic activity, anti-tumor.

\section{INTRODUCTION}

Allamanda (Apocynaceae) is a genus of tropical climbing shrubs, which is known for producing compounds with a range of biological activities, including algicidal (Coppen, 1983; Coppen and Cobb, 1983), antifungal (Tiwari et al., 2002) and antitumoral activities on culture cells (Kupchan et al., 1974; Anderson et al., 1988; Navarro Schmidt et al., 2006). Also their popular therapeutic uses have been reported (Agra et al, 2007; 2008). Previous works have shown the inhibitory effect of Allamanda schottii ethanolic extract on the growth of K562 leukemic cells (Navarro Schmidt et al., 2006). It was also demonstrated that isoplumericin, plumericin and scopoletin, all isolated from A. schottii, have presented cytotoxicity against 9KB (human nasopharyngeal carcinoma) and 3PS (P388 murine leukemia) cells (Anderson et al., 1988).

For several years embryos and eggs of sea urchin have been used as a model for studying cell division and embryologic development (Epel, 1963; Hinchcliffe et al., 1998; Terasaki, 2000). Also, this model has been utilized to detect the cytotoxic and teratogenic activities of new compounds (Morale et al., 1998; Costa-Lotufo et al., 2002b; Hansen et al., 2003; Jimenez et al., 2003). Recently, some works have emphasized the study of alterations in sea urchin egg development as a multicellular model for evaluating anti-tumor activity (Costa-Lotufo et al., 2002a; CostaLotufo et al., 2003; Knudson, 2004; Costa-Lotufo et al., 
2005).

Considering the therapeutic potentialities of the Allamanda schottii, the present work was conducted to evaluate the effects of dichloromethane fraction obtained from aerial parts of this plant on sea urchin Echinometra lucunter eggs development as a multicellular model for investigate the anti-tumor potential of this fraction.

\section{MATERIAL AND METHODS}

\section{Plant material}

Samples of $A$. schottii were collected in Florianópolis, SC, Brazil, in 2002. A voucher specimen was identified by Prof. Benigno Iza (UNIVALI) and has been deposited at the Barbosa Rodrigues Herbarium, Itajaí, under the number HRB 52525. Dried leaves and stems of $A$. schottii were extracted exhaustively with $95 \%$ ethanol by maceration for seven days. Crude extracts of the organs were obtained at reduced pressure and temperatures below $60^{\circ} \mathrm{C}$. Fractionation of $A$. schottii involved liquid-liquid partition with dichloromethane giving the respective fraction, as described in Navarro Schmidt et al. (2006). From dichloromethane (DCM) fraction the following compounds were isolated: a mixture of the phytosterols $\beta$ sitosterol and stigmasterol, the iridoids plumericin and plumieride, the coumarin scopoletin, and the triterpenoid ursolic acid, which were identified on the basis of spectroscopic data, and specifically by comparison of their IV, RMN ${ }^{1} \mathrm{H}$ and ${ }^{13} \mathrm{C}$ data with those in literature (Navarro Schmidt et al., 2006). The DMC fraction was dissolved in dimethylsulfoxide (DMSO) for anti-mitotic analysis.

\section{Evaluation of anti-mitotic activity}

The evaluation of the anti-mitotic activity of the DCM fraction was made as described by Costa-Lotufo et al. (2002). Sea urchins (Echinometra lucunter Linnaeus, 1758) were collected in Intermares beach, Paraíba, Northeastern Brazil ( $7^{\circ} 01^{\prime} 55.55^{\prime \prime} \mathrm{S} 34^{\circ} 49^{\prime} 14.96$ "W). Spawning was induced by injecting $3.0 \mathrm{~mL}$ of a $0.5 \mathrm{M}$ $\mathrm{KCl}$ solution into the perivisceral cavity. The eggs were washed three times in filtered sea water (FSW) in order to remove the jelly coat. The concentrated sperm was collected with a Pasteur pipette, and then was diluted 1:50 with FSW. Fertilization was performed by adding $1 \mathrm{~mL}$ of sperm suspension to $100 \mathrm{~mL}$ of FSW containing the eggs. After the confirmation of the fertilization (by the elevation of the fertilization membrane), the number of eggs was adjusted to $10^{4}$ eggs $/ \mathrm{mL}$ and $1 \mathrm{~mL}$ of the suspension of fertilized eggs were transferred to each well of 24-well plates. DCM fraction dissolved in DMSO was diluted in concentrations ranging from 5 to $200 \mu \mathrm{g} / \mathrm{mL}$ with FSW. DMSO was used as negative control. The eggs were incubated in a final volume of 2 $\mathrm{mL}$ at $25^{\circ} \mathrm{C}$. With the purpose of obtaining first and third cleavages, and blastulae, $200 \mu \mathrm{L}$ of the egg suspension was collected and fixed in the same volume of ISOTON solution $(10.5 \mathrm{~g}$ citric acid, $7.0 \mathrm{~g} \mathrm{NaCl}, 5.0 \mathrm{~mL}$ formalin and $1000 \mathrm{~mL}$ distilled water) $1.5 \mathrm{~h}, 3 \mathrm{~h}$ and $7 \mathrm{~h}$ after fertilization, respectively. To obtain the percentage of normal development, one hundred eggs or embryos were counted for each concentration of the fraction tested.

\section{Statistical analysis}

The concentration that inhibits the normal development of $50 \%$ of the eggs $\left(\mathrm{IC}_{50}\right)$ and its $95 \%$ confidence intervals were determined by probit regression using the SPSS 8.0 for Windows program. The differences between experimental groups were compared by Student's test and values of $\mathrm{p}<0.05$ were considered significant.

\section{RESULTS AND DISCUSSION}

Dichloromethane (DCM) fraction of A. schottii presented strong anti-mitotic activity against sea urchin embryos. Figure 1 shows the concentration-dependent effect of the fraction on the division cycles of sea urchin embryos. The $\mathrm{IC}_{50}$ values for first and third cleavage and blastulae were 103.7 (76.5-148.3) $\mu \mathrm{g} / \mathrm{mL}, 33.1$ (27.140.1) $\mu \mathrm{g} / \mathrm{mL}$ and $10.2(6.8-14.3) \mu \mathrm{g} / \mathrm{mL}$, respectively. The inhibition of the first cleavage was evident when DCM was tested at $100 \mu \mathrm{g} / \mathrm{mL}$, when approximately $40 \%$ of the embryos were blocked at one-cell stage (Figure 2A and 2B). After seven hours of incubation, $100 \%$ of the embryos in control were at blastula stage (Figure 2C), while in the presence of $30 \mu \mathrm{g} / \mathrm{mL}$ of DCM fraction the development was blocked at 2-, 4-, 8-, 16cell stage (Figure 2D). At this time, concentrations as low as $15 \mu \mathrm{g} / \mathrm{mL}$ inhibited significantly the development of sea urchin eggs and approximately $60 \%$ of these did not reach the blastula stage (results not showed). Larva stage was apparent $28 \mathrm{~h}$ after fertilization in control group (Figure 2E). Figure 2F demonstrates the potent effect of DCM fraction at $15 \mu \mathrm{g} / \mathrm{mL} 28 \mathrm{~h}$ after fertilization, showing abnormal and dead embryos, with development blocked at blastula stage. At the lowest concentration tested $(5 \mu \mathrm{g} / \mathrm{mL})$, the fraction impairs the normal development of sea urchin embryos into larva stage (results not showed). These results demonstrate the cumulative effect of the DCM fraction obtained from A. schottii on sea urchin embryos.

In the present work, we demonstrated the strong anti-mitotic effect of DCM fraction towards sea urchin egg development. This model has been used for evaluating anti-tumor activity (Costa-Lotufo et al., 2003; Knudson, 2004; Costa-Lotufo et al., 2005). Our results on this multicellular model corroborate previous work in which the anti-proliferative effect of extract of A. schottii on leukemic cells was described (Navarro Schmidt et al., 2006). 


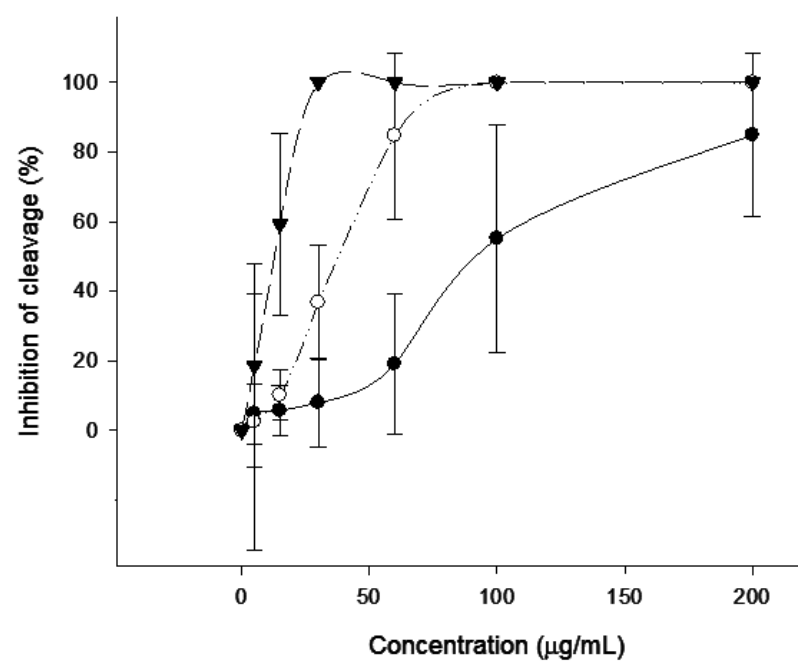

Figure 1. Effect of DCM fraction obtained from A. schottii on sea urchin Echinometra lucunter egg cleavage. Values are mean ( \pm standard errors) of three different experiments for the first (solid circles) and third (open circles) cleavages and blastula stage (filled triangles). DMSO was used as negative control.

Some compounds also present in the DCM fraction of $A$. schottii (Navarro Schmidt et al., 2006), have previously been show to have antitumoral properties on culture cells. Scopoletin is known to have anti-proliferative activity against several cancer cell lines (Anderson et al., 1988; Manuele et al, 2006). It was also demonstrated that scopoletin induces apoptosis in HL-60 cell line (Kim et al., 2005). Plumericin presents antitumoral properties and is also known to cause DNA damage (Kupchan et al., 1974; Anderson et al., 1988; Wood et al., 2001). Sitosterol was reported to inhibit the growth of tumoral cell lines, and the mechanisms by which this compound act include induction of apoptosis, inhibition of cell cycle progression, prostaglandin synthesis and the production of reactive oxygen species (ROS) (Awad et al., 2003; Choi et al., 2003; Awad et al., 2005). The ursolic acid, also present in the DCM fraction of $A$. schottii as the major compound (Navarro Schmidt et al., 2006), is recognized as a potent antiproliferative agent, which blocks cell cycle progression (Es-saady et al., 1996; Li et al., 2002; Hsu et al., 2004). It is important to stress that ursolic acid is also an inhibitor of DNA polymerase and DNA topoisomerase, two important cellular targets for chemical intervention in the development of anti-cancer agents (Mizushina et al., 2000).

In the present work, the expressive anti-mitotic activity of the DMC fraction towards sea urchin eggs, a muticellular model, reinforces the anti-tumor potential of the Allamanda schotti. The synergic effect of the different compounds present in this fraction is likely to be responsible for the anti-proliferative effect of this plant derivative.

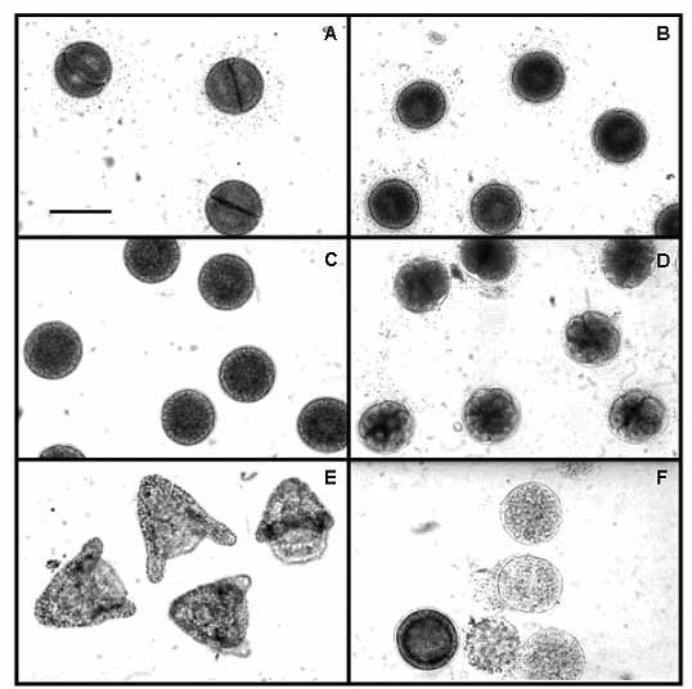

Figure 2. Photomicrographs showing the effect of DCM fraction of A. schottii on first cleavage (A and B), blastula (C and D) and larva (E and F) stage of sea urchin development. Control (A) and $100 \mu \mathrm{g} / \mathrm{mL}$ DCM fraction (B), 1.5 hours after fertilization. Control (C) and $30 \mu \mathrm{g} / \mathrm{mL}$ DCM fraction (D), 6 hours after fertilization. Control (E) and $15 \mu \mathrm{g} / \mathrm{mL}$ DCM fraction (F), 28 hours after fertilization. Bar $=100 \mu \mathrm{m}$.

\section{ACKNOWLEDGMENTS}

We wish to thank Nívea Maria Rocha Macedo (Faculdade de Medicina de Ribeirão Preto, University of São Paulo) and Paula Christine Jimenez (Universidade Federal do Ceará) for helpful advices on the experimental model sea urchin. We also acknowledge Alberto Sousa for correcting the English manuscript.

\section{REFERENCES}

Agra MF, França PF, Barbosa-Filho JM 2007. Synopsis of the plants known as medicinal and poisonous in Northeast of Brazil. Rev Bras Farmacogn 17: 114-140.

Agra MF, Silva KN, Basílio IJLD, França PF, Barbosa-Filho JM 2008. Survey of medicinal plants used in the region Northeast of Brazil. Rev Bras Farmacogn 18: 472508.

Anderson JE, Chang CJ, McLaughlin JL 1988. Bioactive components of Allamanda schottii. J Nat Prod 51: 307-308.

Awad AB, Roy R, Fink CS 2003. $\beta$-sitosterol, a plant sterol, induces apoptosis and activates key caspases in MDAMB-231 human breast cancer cells. Oncol Rep 10: 497-500.

Awad AB, Burr AT, Fink CS 2005. Effect of resveratrol and $\beta$-sitosterol in combination on reactive oxygen species and prostaglandin release by PC3 cells. Prostaglandins Leukot Essent Fatty Acids 72: 219-226.

Choi YH, Kong KR, Kim YA, Jung KO, Kil JH, Rhee SH, Park KY 2003. Induction of Bax and activation of caspases during $\beta$-sitosterol-mediated apoptosis in human colon cancer cells. Int J Oncol 23: 1657-1662.

Coppen JJW 1983. Iridoids with algicidal properties from Allamanda cathartica. Phytochemistry 22: 179-182.

Coppen JJW, Cobb AL 1983. The occurrence of iridoids in Plumeria and Allamanda. Phytochemistry 22: 125128. 
Costa-Lotufo LV, Cunha GMA, Farias PAM, Viana GSB, Cunha KMA, Pessoa C, Moraes MO, Silveira ER, Gramosa NV, Rao VSN 2002a. The citotoxic and embryotoxic effects of kaurenoic acid, a diterpene isolated from Copaifera langsdorffii oleo-resin. Toxicon 40: 12311234.

Costa-Lotufo LV, Ferreira MAD, Lemos TIG, Pessoa ODL, Viana GSB, Cunha GMA 2002b. Toxicity to sea urchin egg development of the quinine fraction obtained from Auxema oncocalyx. Braz J Med Biol Res 35: 927-930.

Costa-Lotufo LV, Jimenez PC, Wilke DV. Leal LKAM, Cunha GMA, Silveira ER, Canuto KM, Viana GSB, Moraes MEA, Moraes MO, Pessoa C 2003. Antiproliferative effects of several compounds isolated from Amburana cearensis A.C. Smith. Z Naturforsch C 56: 675-680.

Costa-Lotufo LV, Khan MTH, Ather A, Wilke DV, Jimenez PC, Pessoa C, Moraes MEA, Moraes MO 2005. Studies of the anticancer potential of plants used in Bangladeshi folk medicine. J Ethnopharmacol 99: 21-30.

Epel D 1963. The effects of carbon monoxide inhibition on ATP level and the rate of mitosis in the sea urchin egg. $J$ Cell Biol 17: 315-319.

Es-Saady D, Simon A, Ollier M, Maurizis JC, Chulia AJ, Delage C 1996. Inhibitory effect of ursolic acid on B16 proliferation through cell cycle arrest. Cancer Lett 106: 193-197.

Hansen, E, Eilertsen HC, Ernstsen A, Genevière A 2003. Antimitotic activity towards sea urchin embryos in extracts from the marine haptophycean Phaeocystis pouchetti (Hariot) Lagerheim collected along the coast of northern Norway. Toxicon 41: 803-812.

Hinchcliffe ED, Cassels GO, Rieder CL, Sluder G 1998. The coordination of centrosome reproduction with nuclear events of the cell cycle in the sea urchin zygote. $J$ Cell Biol 140: 1417-1426.

Hsu YL, Kuo PL, Lin CC 2004. Proliferative inhibition, cellcycle dysregulation, and induction of apoptosis by ursolic acid in human non-small cell lung cancer A549 cells. Life Sci 75: 2303-2316.

Jimenez PC, Fortier SC, Lotufo, TMC, Pessoa C, Moraes MEA, Moraes MO, Costa-Lotufo LV 2003. Biological activity in extracts of ascidians (Tunicata, Ascidiacea) from the northeastern Brazilian coast. J Exp Marine Biol Ecol 287: 93-101.

Kim EK, Kwon KB, Shin BC, Seo EA, Lee YR, Kim JS, Park JW, Park BH, Ryu DG 2005. Scopoletin induces apoptosis in human promyeloleukemic cells, accompanied by activations of nuclear factor $\mathrm{\kappa B}$ and caspase-3. Life Sci 77: 824-836.

Knudson AG 2004. Of sea urchin and worms: development and cancer. Cell Death Differ 11: 11-12.

Kupchan SM, Dessertine BT, Blaylock BT, Bryan RT 1974. Isolation and structural elucidation of allamandin, an antileukemic iridoid lactone from Allamanda cathartica. J Org Chem 39: 2477-2482.

Li J, Guo WJ, Yang QY 2002. Effects of ursolic acid and oleanolic acid on human colon carcinoma cell line HCT15. World J Gastroenterol 8: 493-495.

Manuele MG, Ferraro G, Arcos MLB, López P, Cremaschi G, Anesini C 2006. Comparative immunomodulatory effect of scopoletin on tumoral and normal lymphocytes. Life Sci 79: 2043-2048.

Mizushina Y, Iida A, Ohta K, Sugawara F, Sakaguchi K 2000. Novel triterpenoids inhibit both DNA polymerase and DNA topoisomerase. Biochem J 350: 757-763.

Morale A, Coniglio L, Angelini C, Cimoli G, Bolla A, Alleteo D, Russo P, Falugi C 1998. Biological effects of a neurotoxic pesticide at low concentrations on sea urchin early development. A terathogenic assay. Chemosphere 37: 3001-3010.

Navarro Schmidt DF, Yunes RA, Schaab EH, Malheiros A, Cechinel Filho V, Franchi GC, Nowill AE, Cardoso AA, Yunes JA 2006. Evaluation of the anti-proliferative effect the extracts of Allamanda blanchetti and Allamanda schottii on the growth of leukemic and endothelial cell. J Pharm Pharm Sci 9: 200-208.

Terasaki M 2000. Dynamics of the endoplasmic reticulum and golgi apparatus during early sea urchin development. Mol Biol Cell 11: 897-914.

Tiwari TN, Pandey VB, Dubey NK 2002. Plumieride from Allamanda cathartica as an antidermatophytic agent. Phytother Res 16: 393-394.

Wood CA, Lee K, Vaisberg AJ, Kingston DGI, Neto CC, Hammond GB 2001. A bioactive spirolactone iridoid and triterpenoids from Himatanthus sucuuba. Chem Pharm Bull 49: 1477-1478. 